\title{
ЗВОРОТНИЙ ЗВ'ЯЗОК ЯК ІНСТРУМЕНТ УДОСКОНАЛЕННЯ ЯКОСТІ ОСВІТИ ІНОЗЕМНИХ СТУДЕНТІВ У МЕДИЧНИХ ВИЩИХ НАВЧАЛЬНИХ ЗАКЛАДАХ УКРАЇНИ
}

\author{
Л. Р. Шостакович-Корецька, В. В. Маврутенков, А. В. Чергінець, І. В. Будаєва, \\ О. М. Якуніна, 3. О. Чикаренко, М. А. Ніколайчук, Ахмад Аль-Дірані (Ліван) \\ ДЗ “Дніпропетровська медична академія МОЗ України”
}

\section{FEEDBACK AS INSTRUMENT OF IMPROVEMENT OF EDUCATION QUALITY OF FOREIGN STUDENTS IN HIGH MEDICAL INSTITUTIONS OF UKRAINE}

\author{
L. R. Shostakovych-Koretska,V. V. Mavrutenkov, A. V. Cherhinets, I. V. Budayeva, \\ O. M. Yakunina, Z. O. Chykarenko, M. A. Nikolaichuk, Akhmad Al-Dirani (Lebanon) \\ SI "Dnipropetrovsk Medical Academy of MPH of Ukraine"
}

\begin{abstract}
Питання досконалості і якості медичної освіти іноземним студентам у медичних вищих навчальних закладах України потребують подальшого вивчення, і першим кроком у цьому напрямку може бути анкетування іноземних випускників. В роботі проведений аналіз результатів анкетування іноземних випускників, які отримали вищу освіту у ДЗ “Дніпропетровська медична академія МОЗ України” $з$ метою пошуків заходів подальшого удосконалення системи управління навчально-методичного супроводу освітнього процесу і вдосконалення професійної компетентності викладачів. Результати роботи дозволили зробити такі висновки: застосування методу зворотного зв'язку може бути інструментом для удосконалення організації освітнього процесу; з метою прискорення нострифікації дипломів про вищу медичну освіту слід адаптувати систему ліцензійних іспитів в Україні для студентів з урахуванням країн походження; залучення випускників академії, що досягли певних успіхів у професійній діяльності, до інформаційних засобів може сприяти популяризації медичних вищих навчальних закладів в Україні.
\end{abstract}

Problems of improvement and quality of medical education for foreign students in high medical institutions of Ukraine require further investigation, and the first step in this direction can be questionnaires of foreign students. In the study the analysis of questionnaires of foreign graduates who obtained education in SI "Dnipropetrovsk Medical Academy of MPH of Ukraine" is presented with the goal of searching further methods of system improvement of management of study-methodical accompaniment of educational process and improvement of professional competency of teachers. Working results allowed obtain the following conclusions: usage of feedback method can be the instrument for improvement of educational process organization; with the goal of rapidness of diploma nostrification of high medical education it is reasonable to adapt the system of license examinations in Ukraine for the students considering their countries of origin; inviting academy graduates who reached certain success in their professional activity into informational methods can facilitate popularization of Higher Medical Institutions in Ukraine.

Вступ. В теперішній час у ДЗ “Дніпропетровська медична академія МОЗ України” (ДЗ ДМА) на трьох факультетах: I, II та факультеті післядипломної освіти навчаються 1333 іноземних громадяни з 42 різних країн, що складає близько 30 \% від всіх студентів у виші [1]. Кожного року кількість іноземних студентів у ВНЗ України збільшується, що є позитивним фактом і свідчить про престижність набуття вищої освіти в Україні.

Водночас питання досконалості і якості медичної освіти іноземним студентам у вишах України по- требують подальшого вивчення, і першим кроком у цьому напрямку може бути анкетування іноземних випускників для отримання зворотного зв'язку після завершення навчання $і$ аналізу навчально-методичного супроводу освітньої системи. Здійснення зворотного зв'язку не тільки в процесі навчання, але також після його завершення дозволяє надати нового формату навчальному процесу, врахувати як плюси, так і мінуси.

Залучення контингенту іноземних студентів ставить до медичного вишу ряд вимог: 1) відповідати світовим стандартам вищої медичної освіти; 2) мати

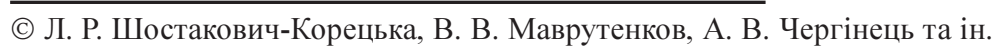


визнання в національних системах охорони здоров'я; 3) створювати сприятливий соціально-психологічний, культурологічний та політичний клімат для адаптації в нових умовах $[2,3]$.

Основна частина. Ціль роботи - провести аналіз результатів анкетування іноземних випускників, які отримали вищу освіту в Д3 “Дніпропетровська медична академія МО3 України” для удосконалення системи управління навчально-методичного супро- воду освітнього процесу і вдосконалення професійної компетентності викладачів.

Для вирішення поставленої мети було проведено вибіркове інтернет-опитування випускників ДЗ ДМА 2011 -2012 pp. (n-40), які отримали диплом за фахом “Лікувальна справа" (табл. 1).

Всі випускники були громадянами країн Близького Сходу. У гендерному відношенні серед респондентів з великою перевагою домінували чоловіки.

Таблиця 1. Контингент респондентів, що взяли участь в інтернет-опитуванні випускників ДЗ ДМА 2011/2012 рр.

\begin{tabular}{|c|c|c|c|}
\hline 4 & курд $(\mathrm{p}$ & K ${ }^{0} 05 \mathrm{~K}^{\circ} 6 \mathrm{~m}$ & пе( теу( ні роНекмМСАХ \\
\hline$\Phi$ & a $\%$ жр ( о5Кр в еоНВ, ) \%бр & 0 & $0 \mathrm{Q}$ \\
\hline 6 & 7 p) еомн( о5Кр рхм8( 8П\% & я & яQ \\
\hline 3 & ф8утр( о5Ке л рь нП0б5К к 8у8) 0\%омх8 & 3 & $3 \mathrm{Q}$ \\
\hline ю & 2 ну\%\%о5Кр ц урдо5Кр в еоНВд) \%бр & $\Phi$ & $\Phi \mathrm{Q}$ \\
\hline я & к 8у8) \%бомх8 и ру8ҚК & ч & йळ \\
\hline $\mathrm{x}$ & $<3\left({ }^{\circ} 65\right.$ Кр в еоНВд) \%бр & 3 & 6Ф \\
\hline
\end{tabular}

До респондентів були поставлені чотири питання, які, на нашу думку, відображали соціальні аспекти набуття вищої медичної освіти в указаному закладі:

1. Професійна адаптаџฺія: Ви підтвердили свій диплом і працюєте зараз лікарем? (так/ні)

2. Перспективи освіти: Порекомендували би Ви своїм співвітчизникам здобувати вищу медичну освіту в Україні? (так/ні)

3. Визнання та підтвердження статусу лікаря: Чи мали Ви певні труднощі після набуття освіти в Україні при:

- підтвердженні диплома;

- при працевлаштуванні;

- при спілкуванні з пацієнтами і відмові їх від обслуговування? (так/ні)

4. Культурологічний та психологічний аспекти: Чи змінилося Ваше ставлення до України та українців у цілому після закінчення навчання? так ( $\uparrow-$ позитивно), так ( $\downarrow$ - негативно), ні (ч нейтрально).

Результати анкетування показали, що 80 \% (n-38) випускників ДЗ ДМА підтвердили диплом “українського" фахівця у відповідних національних департаментах охорони здоров'я, змогли професійно адаптуватися і мали працевлаштування за спеціальністю (табл. 2). Решта респондентів (20 \%) не зуміли підтвердити диплом фахівця у своїй країні, всі вони є громадянами Сирії.

В аспекті “перспектив освіти” більшість респондентів-випускників (80 \%) позитивно оцінила рівень та організацію навчання в ДЗ ДМА і збирається ре- комендувати співвітчизникам здобувати вищу медичну освіту в Україні, зокрема в Дніпропетровській медичній академії.

Що стосується визнання та підтвердження статусу лікаря, то цей аспект заслуговує особистої уваги. Майже всі випускники зіткнулися із труднощами при працевлаштуванні на роботу, або підтвердженні диплома, або з відмовою пацієнтів при медичному обслуговуванні. На думку респондентів, причинами таких проблем є: по-перше, досить розповсюджена в країнах Близького Сходу думка про невисокі вимоги до вступу та навчання в системі вищої медичної освіти в країнах СНД; по-друге, низький рівень результатів кваліфікаційних іспитів при нострифікації українського диплома в національних системах охорони здоров'я, що вимагає повторного перескладання іспитів.

Головною причиною невдач при нострифікації “уукраїнських" дипломів, на думку респондентів, є невідповідність системи іспитів в Україні до національних систем контролю якості вищої медичної освіти в ї країнах.

Аналіз “культурологічного та психологічного аспектів” отримання освіти в Україні свідчить про те, що більшість респондентів (95 \%) після закінчення навчання і початку самостійного трудового життя підвищила своє позитивне ставлення до України. Тільки 2 респонденти висловили негативізм до України. Основними причинами негативної оцінки були: побутові умови і факти етнофобіiі. 
Таблиця 2. Результати інтернет-опитування іноземних випускників ДЗ ДМА 2011/2012 рр.

\begin{tabular}{|l|c|c|c|c|}
\hline \multicolumn{1}{|c|}{ Країна (n- ) } & $\begin{array}{c}\text { Професійна } \\
\text { адаптація (так/ні) }\end{array}$ & $\begin{array}{c}\text { Перспективи освіти } \\
(\text { так/ні) }\end{array}$ & $\begin{array}{c}\text { Реальність } \\
\text { (так/ні) }\end{array}$ & $\begin{array}{c}\text { Культурологічний та } \\
\text { психологічний аспекти } \\
(\uparrow / \downarrow / \div)\end{array}$ \\
\hline $\begin{array}{l}\text { Ліванська } \\
\text { Республіка }\end{array}$ & $7 / 0$ & $7 / 0$ & $7 / 0$ & $\uparrow(\mathrm{n}-7)$ \\
\hline $\begin{array}{l}\text { Палестинська } \\
\text { автономія }\end{array}$ & $5 / 0$ & $5 / 0$ & $5 / 0$ & $\uparrow(\mathrm{n}-3)$ \\
\hline $\begin{array}{l}\text { Йорданське } \\
\text { Хашимітське } \\
\text { Королівство }\end{array}$ & $3 / 0$ & $2 / 1$ & $3 / 0$ & $\uparrow(\mathrm{n}-11) / \downarrow(\mathrm{n}-2)$ \\
\hline $\begin{array}{l}\text { Сирійська } \\
\text { Арабська } \\
\text { Республіка }\end{array}$ & $8 / 5$ & $10 / 3$ & $9 / 0$ & $\uparrow(\mathrm{n}-9)$ \\
\hline $\begin{array}{l}\text { Королівство } \\
\text { Марокко }\end{array}$ & $9 / 0$ & $8 / 1$ & $3 / 0$ & $\uparrow(\mathrm{n}-3)$ \\
\hline $\begin{array}{l}\text { Туніська } \\
\text { Республіка }\end{array}$ & $3 / 0$ & $3 / 0$ & $40 / 0$ & $\uparrow(\mathrm{n}-38) / \downarrow(\mathrm{n}-2)$ \\
\hline Всього & $35 / 5$ & $35 / 5$ & & \\
\hline
\end{tabular}

В цілому, можна стверджувати, що існуюча організація навчального процесу в ДЗ ДМА дозволила нашим респондентам задовольнити особисті мотивації в здобутті професії лікаря, незважаючи на окремі недоліки освітнього процесу і проблеми соціально-психологічного характеру. Визначення більшістю респондентів, випускників Дніпропетровської медичної академії, того, що їм вдалося досягнути кінцевої мети навчання, безумовно сприяє поширенню у світі позитивного іміджу України, як країни з доступною і якісною вищою медичною освітою.

Висновки: 1. Зростання питомої ваги іноземних студентів у медичних вишах за останні роки свідчить

\section{Література}

1. Державний заклад “Дніпропетровська медична академія Міністерства охорони здоров’я України”; ресурс: http:/ /www.dsma.dp.ua/for-foreign про позитивний рейтинг нашої держави, як країни 3 доступною та якісною освітою.

2. Застосування методу зворотного зв'язку може бути інструментом для удосконалення організації освітнього процесу.

3. 3 метою прискорення нострифікації дипломів про вищу медичну освіту слід адаптувати систему ліцензійних іспитів в Україні для студентів з урахуванням країн походження.

4. Залучення випускників академії, що досягли певних успіхів у професійній діяльності, до інформаційних засобів може сприяти популяризації медичних вишів в Україні.

2. Study in Ukraine; pecypc: http://www.edu-ukraine.com/ why-study-in-ukraine.html

3.Arabia-Ukraine.com; pecypc: http://arabia-ukraine.com/ 